\title{
THE LATIN AMERICAN JOURNAL OF NURSING CELEBRATES ITS 15TH ANNIVERSARY
}

\author{
Maria Helena Palucci Marziale \\ Isabel Amélia Costa Mendes²
}

The year that starts is very significant for the University of São Paulo at Ribeirão Preto College of Nursing, as the institution celebrates its $55^{\text {th }}$ anniversary and 20 years of work as a WHO Collaborating Centre for Nursing Research Development. RLAE, its scientific journal, is commemorating Nursing15 years of circulation, having published 77 issues and 1207 articles so far, currently in bimonthly editions.

A comparative analysis of the current characteristics of the Latin American Journal of Nursing (RLAE) and those of the previous five years ${ }^{(1)}$ shows significant advances in the visibility of the journal, as a result of better editorial policies and improvement in the quality of the papers published.

In relation to visibility, five years ago, RLAE was already indexed in renowned national and international databases, such as MEDLINE, CINAHL, CAB HEALTH, CAB ABSTRACTS, PSYCINFO, CUIDEN, LILACS, BDENF, EDUBASE, and the SCIELO Brasil collection. In the last five years, the journal has advanced further, with its inclusion in the WEB of SCIENCE, SCOPUS, LATINDEX, PERIODICA and CUIDATGE. Among the last achievements, we underline its inclusion in the Web of Science, which consists of three databases ("Science Citation Index Expanded", Arts \& Humanities Citation Index y "Social Sciences Citation Index") elaborated by the Institute for Scientific Information (ISI), and which keeps record of more than eight thousand titles of the most renowned journals of the world, as well as recently published books, proceedings and reviews.

On the other hand, the SCOPUS - Elsevier database is a new navigation tool that comprises about fifteen thousand journals and allows direct access to the entire paper contents with the aid of links. Therefore, indexing in the SCOPUS and SCIELO databases will greatly enhance the visibility of the journal, due to the possibility those databases give of free access to the articles. We think that this may be a good strategy for those journals seeking to increase the number of citations of the papers they publish.

In recent years, RLAE has ranked among the four most visited titles in the Scielo Brasil collection ${ }^{(2)}$, among 205 available titles. The average number of external citations per article has strongly increased, from 0.11 in 1993 to 0.65 in 2003 and to 2.84 in 2007.

The articles published in Portuguese, Spanish and English are available electronically, as well as in print in English; the adoption of an on-line system for submitting and processing papers, and the choice of subjects for special issues that are in accordance with national and international guidelines are all part of an editorial policy that is grounded in international publishing concepts.

The journal's top priority is to publish original research articles; and with the purpose of publishing papers that contribute to the advance of Nursing knowledgeNursing, its Advisory and Editorial boards maintain a high standard related to the quality of the articles that are accepted for publication.

On this $15^{\text {th }}$ anniversary of RLAE, we have many achievements to celebrate. However, other challenges lie ahead:

- to increase the publication of papers that are well prepared methodologically, containing well founded analysis and discussions of data and results, which contribute to the advancement of knowledge in Nursing

- to diversify and increase international contributions, to be used as a vehicle for publishing articles from several regions of the world

- to obtain a good citation index in international databases

- to attract financial resources

- to improve the electronic system for article submission and journal management

- to reduce the publishing time of articles

Editors of Latin American Journal of Nursing of Ribeirão Preto of the University of São Paulo at Ribeirão Preto College of Nursing - WHO Collaborating Centre for Nursing Research Development, Brazil: ${ }^{1}$ Full Professor, e-mail: marziale@eerp.usp.br; ${ }^{2}$ Full Professor, e-mail: iamendes@eerp.usp.br 
We feel greatly indebted to the research community of Nursing, the consultants, the Editorial Board, the Executive Board, and the whole RLAE team, as well as to the sponsors, for all their contributions during all these years, and we hope to continue relying on everyone's support to make this young journal an internationally renowned vehicle for disseminating Nursing knowledgeNursing.

We now proceed to present the stamp in commemoration of the journal's anniversary.

\section{REFERENCES}

1. Marziale MHP, Mendes IAC. Dez anos contribuindo para memória da ciência: Revista Latino-Americana de Enfermagem. Rev Latino-am Enfermagem [periódico on-line] 2003 março-abril [citado em 2 de abril de 2007]; 11(2):143-5. Disponível em:http:/ /www.scielo.br/scielo.php?script=sci_arttext\&pid=S0104-11692003000200001\&nrm =iso

2. Scielo Brasil. Relatórios de utilização do site. 10 títulos mais visitados. Discponivel.2008. http://scielo-log.bireme.br/ scielolog/ofigraph20.php?app=scielo. Acessado em 2/2/08. 